\title{
ANALISIS PERIBAHASA MINANGKABAU DI PASAMAN BARAT KAJIAN BENTUK FUNGSI DAN MAKNA
}

\author{
${ }^{1}$ Danil Saputra, ${ }^{2}$ Suryadi, ${ }^{8}$ Supadi \\ ${ }^{1,2,3}$ Universitas Bengkulu
}

\begin{abstract}
Abstrak
Korepondensi: danilsaputra250@gmail.com

Tujuan penelitian ini adalah untuk mendeskripsikan bentuk peribahasa Minangkabau, fungsi peribahasa Minangkabau, serta makna peribahasa Minangkabau yang ada di Pasaman Barat. Metode yang digunakan dalam penelitian ini adalah metode deskriptif. Sumber data dalam penelitian ini adalah tuturan yang mengandung peribahasa yang diperoleh dari informan yang terdiri atas tokoh masyarakat. Teknik pengumpulan data yang digunakan dalam penelitian ini adalah teknik wawancara, teknik rekam dan terknik catat, serta teknik simak. Langkah-langkah analisis data dalam penelitian ini adalah transkripsi data, identifikasi data, klasifikasi data, interpretasi data, dan membuat kesimpulan akhir. Hasil penelitian ini menunjukan bahwa peribahasa Minangkabau memiliki 8 bentuk peribahasa yaitu (1) kiasan, (2) mamang, (3) pemeo, (4) tamsil, (5) ibarat, (6) kata-kata arif, (7) petatah-petitih, dan (8) perumpamaan. Peribahasa Minangkabau memiliki 5 fungsi yaitu (1) sebagai media pendidikan dan pedoman tingkah laku, (2) sebagai pengatur aspek-aspek kehidupan bermasyarakat, (3) sebagai sumber hukum, pengasuh pranata sosial, pengawas dan pengukuh normanorma sosial, (4) sebagai lambang identitas budaya dan sumber informasi budaya, (5) sebagai media serta sarana retorika untuk mematahkan kata-kata lawan bicara (alat pertahanan diri). Peribahasa Minangkabau memiliki 7 makna atau nilai-nilai yang terkandung dalam peribahasa Minangkabau yaitu (1) teguh pendirian, (2) malu, (3) nilai etika, (4) tahu diri, (5) menjaga diri, (6) persatuan/mufakat, dan (7) kesabaran.
\end{abstract}

Kata kunci : Analisis, Peribahasa Minangkabau, Pasaman Barat, kajian bentuk, fungsi, makna

\section{Abstract}

The purpose of this research is to describe the form of Minangkabau proverbs, the function of Minangkabau proverbs, and the meaning of Minangkabau proverbs in West Pasaman. The method used in this research is descriptive method. Sources of data in this study are utterances containing proverbs obtained from informants consisting of community leaders. Data collection techniques used in this study were interview techniques, recording techniques and note-taking techniques, and listening techniques. The data analysis steps in this study were data transcription, data identification, data classification, data interpretation, and making final conclusions. The results of this study indicate that Minangkabau proverbs have 8 proverbs, namely (1) figurative, (2) mamang, (3) byword, (4) simile, (5) likeness, (6) wise words, (7) paraphrase, and (8) parable. Minangkabau proverbs have 5 functions, namely (1) as a medium for education and guidelines for behavior, (2) as a regulator of aspects of social life, (3) as a source of law, carer of social institutions, supervisor and enforcer of social norms, (4) as a symbol of cultural identity and a source of cultural information, (5) as a medium and a means of 
rhetoric to break the words of the interlocutor (a means of self-defense). Minangkabau proverbs have 7 meanings or values contained in Minangkabau proverbs, namely (1) persistence, (2) shame, (3) ethical values, (4) self-knowledge, (5) self-preservation, (6) unity / consensus, and (7) patience.

\section{Keywords: Analysis, Minangkabau proverbs, West Pasaman, study of form, function and meaning}

\section{PENDAHULUAN}

Indonesia terdiri dari berbagai suku dengan daerahnya masing-masing, yang didalamnya terdapat berbagai suku bangsa dan budaya, salah satunya suku Minangkabau. Minangkabau umumnya tersebar diberbagai Provinsi di pulau Sumatera seperti Provinsi Sumatera Barat. Provinsi tersebut memiliki peribahasa yang terdapat di Kabupaten Pasaman Barat yang mayoritas masyarakatnya suku Minangkabau.

Menurut Weli febrianto (2018) suku Minangkabau atau disingkat Minang (Jawi) merujuk pada edentitas kultural dan geografis yang ditandai dengan penggunaan bahasa, adat yang menganut sistem kekerabatan matrilineal, dan identitas agama Islam. Secara geografis, persebaran suku Minangkabau meliputi daratan Sumatra Barat, separuh daratan Riau, bagian utara Bengkulu, bagian barat Jambi, pantai barat Sumatera utara, barat daya Aceh, dan Negeri Sembilan di Malaysia.

Suku Minangkabau memiliki budaya peribahasa yang tersebar di seluruh Kabupaten di Sumatera Barat salah satunya, Kabupaten Pasaman Barat. Pasaman Barat merupakan Kabupaten yang masih kental dengan adat istiadat mengenai peribahasa. Peribahasa Minangkabau yang terdapat di Pasaman Barat memiliki ciri khas, ciri khas tersebut tertuang di dalam bahasa nan ampek, yaitu bahaso mandata, behaso melereang, bahaso manurun, dan bahaso mandaki.

Keberadaan Peribahasa Minangkabau di Pasaman Barat sendiri memiliki pengaruh terhadap perkembangan budaya dan adat istiadat di Pasaman Barat, karena peribahasa selain digunakan untuk percakapan, Peribahasa juga digunakan sebagai semboyan suku Minangkabau di Pasaman Barat. Setiap Kecamatan yang terdapat di Pasaman Barat memiliki penutur peribahasa tetap, maksudnya jika ada acara adat, maka penutur peribahasa tetap itulah yang akan diutamakan hadir dalam acara tersebut.

Peribahasa di Pasaman Barat yang ada kebanyakan kata ataupun kalimatnya menggunakan nama-nama hewan dan tumbuhan serta benda mati seperti batu, air, dan pasir. Hal ini membuktikan bahwa masyarakat Minangkabau memiliki fahsafah adat yang berbunyi alam takambang jadi guru ( alam terbentang dijadikan guru ). Maksudnya adalah bahwa semua yang ada di alam bisa dijadikan sebagai pelajaran untuk hidup dan kehidupan.

Peribahasa merupakan tuturan tradisional yang bersifat tetap pemakaiannya mengandung makna kias, tidak mengandung makna simile (Pulungan, 2013: 3). Menurut Pusposaputro (2010: 11) bahwa peribahasa menunjukkan lingkungan dan benda-benda kongkrit yang banyak dijumpai dalam masyarakat. Untuk mengemukakan beberapa contoh: cukup banyak peribahasa yang menggunakan kata: air, gunung, gajah, harimau, dan sebagainya. Pada dasarnya peribahasa merupakan kalimat singkat yang mengkristalisasikan pengalaman mendalam dan panjang. Atau secara nyata dapat disebut: filsafat mini, maka tak mengherankan bahwa peribahasa itu mengandung kebijaksanaan hidup yang melekat pada lingkungan timbulnya peribahasa tersebut.

Danandjaja (1982: 29-30) dalam kajian kontek folklore berpendapat peribahasa adalah istilah lain untuk menyebutkan ungkapan tradisional. Ajaran sastra lisan berupa ungkapan khusus menurut Hutomo dalam Endraswara (2013: 118) menyebutkan ungkapan biasanya lebih bercorak puitis, teratur, berulang-ulang, maksudnya (a) untuk menguatkan ingatan, (b) 
menjaga keaslian sastra lisan supaya tidak berubah. Wujud ungkapan biasanya disampaikan dari mulut ke mulut dan jarang ditulis.

Ganie (2015:155), peribahasa dikenal secara umum sebagai seperangkat kosakata yang berisi ajaran nilai-nilai budaya luhur yang diacu dan berlaku di kalangan suatu anggota masyarakat. Sejak zaman dahulu kala, susunan kata-kata khas yang bersifat anonim ini diwariskan secara turun temurun dari generasi ke generasi. Mula-mula diwariskan secara lisan dari mulut ke mulut, kemudian diwariskan dengan cara dituliskan, yakni setelah orang-orang di kepulauan nusantara mulai mengenal huruf arab (sejak abad ke-13) dan huruf latin (sejak 1860).

Peribahasa adalah kolompok kata atau kalimat yang tetap susunanya, biasanya mengiaskan maksud tertentu ( KBBI Depertamen Pendidikan Nasional 2007: 858). Peribahasa adalah ayat atau kelompok kata yang mempunyai susunan yang tetap dan mengandung pengertian tertentu (Endah 2013:99).

Berdasarkan latar belakang yang telah diuraikan, maka rumusan masalah dalam penelitian ini adalah. Bagaimana bentuk (wujud) peribahasa, bagaimana fungsi peribahasa dan bagaimana makna peribahasa yang terdapat di Pasaman Barat?

Penelitian ini bertujuan untuk mendeskripsiskan bentuk peribahasa, fungsi peribahasa dan juga makna peribahasa yang terdapat di Pasaman Barat

Manfaat yang diharapkan dalam penelitian ini yakni menambah khasanah ilmu dalam bidang linguistik terutama pada analisis kalimat-kalimat peribahasa, serta penelitian ini juga bermafaat untuk penelitian selanjutnya yang akan mengkaji secara lebih luas mengenai peribahasa.

\section{METODE}

Penelitian ini menggunakan pendekatan kualitatif dengan metode deskriptif. Sumber data dalam penelitian ini adalah tuturan yang mengandung peribahasa yang diperoleh dari informan-informan yang menguasai serta memahami dengan baik tentang pemakaian peribahasa. Data penelitian ini adalah ujaran atau tuturan yang berbentuk peribahasa atau mengandung peribahasa yang masih dipakai dan masih ada yang terdapat dalam bahasa Minangkabau di Pasaman Barat.

Teknik pengumpulan data dalam penelitian ini mencakup, teknik wawancara, teknik simak, teknik rekam dan teknik catat.

Dalam penelitian ini dilakukan langkah-langkah sebagai berikut:

1. Transkripsi data

data berupa peribahasa yang diperoleh dari hasil wawancara di Pasaman Barat, kemudian ditranskripsikan dalam bentuk yang sebenarnya, yaitu dituliskan secara keseluruhan.

2 Identifikasi data

data yang dikumpulkan selanjutnya diidentifikasi berdasarkan kajian bentuk, fungsi, dan makna yang terdapat pada peribahasa Minangkabau di Pasaman Barat.

3 Klasifikasi data setelah dilakukan identifikasi data, kegiatan selanjutnya adalah mengklasifikasikan jenis peribahasa yang tergolong kepada bentuk, peribahasa yang tergolong kepada fungsi dan peribahasa yang tergolong kepada makna.

4 Interpretasi data setelah data diklasifikasikan berdasarkan bentuk, fungsi dan maknanya, selanjutnya dilakukan tahap interpretasi kajian data berdasarkan poin-poin yang terdapat pada bentuk, fungsi dan juga makna peribahasa.

5 Membuat kesimpulan akhir mengenai peribahasa yang terdapat di Pasaman Barat berdasarkan kajian bentuk, fungsi dan makna. 


\section{HASIL DAN PEMBAHASAN}

Berdasarkan hasil penelitian yang diperoleh dari data peribahasa yang ada di Pasaman Barat ada tiga aspek sebagai berikut.

1. Bentuk peribahasa yang ada di Pasaman Barat antara lain kiasan, mamang, pemeo, tamsil, ibarat, kata-kata arif, petatah-petitih, dan perumpamaan.

2. Fungsi peribahasa yang terdapat di Pasaman Barat antara lain media pendidikan, pedoman tingkah laku, mengatur aspek-aspek kehidupan bermasyarakat, sebagai sumber hukum, pengesah pranata sosial, pengawas dan pengukuh norma-norma sosial, lambang identitas budaya, dan sumber informasi budaya, dan sebagai media dan sarana retorika untuk mematahkan kata-kata lawan bicara (alat pertahanan diri).

3. Makna peribahasa yang terdapat di Pasaman Barat antara lain teguh pendiri, malu, nilai etika, tahu diri, menjaga diri, persatuan mufakat, dan kesabaran.

Berikut hasil analisis data peribahasa yang terdapat di Pasaman Barat dalam aspek bentuk, fungsi dan juga makna.

\section{Peribahasa berbentuk Kiasan, berfungsi sebagai media dan sarana untuk mematahkan kata-kata lawan bicara. dan bermakna tau diri.}

Bantuak raso manggadangan anak rimau. Terjemahan, Bentuk membesarkan anak harimau, 'Ibarat membesarkan anak harimau.'

Membesarkan Anak hariamau memiliki bentuk kiasan karena ciri-cirinya mengandung perbandingan yang tersirat antara manusia dengan harimau. Jika seorang membesarkan anak hariamau maka akan berdampak buruk untuk dirinya, karena yang dibesarkannya adalah binatang buas, apabila binatang itu besar maka akan menerkamnya.

Gambaran tersiratnya apabila seorang anak dibesarkan oleh orang tuanya, ketika dewasa dia durhaka, maka dia digambarkan seperti anak harimau. Berdasarkan indikator, peribahasa ini memiliki ciri-ciri yang terdiri dari 12 suku kata, antara lain ban-tuak ra-so mang-ga-dang-an a-nak ri-mau.

Peribahasa ini berfungsi sebagai media dan sarana untuk mematahkan kata-kata lawan bicara. Maksudnya, apabila ada seorang anak yang durhaka terhadap orang tuanya, maka peribahasa ini sebagai teguran langsung yang diucapkan seseorang kepadanya dan peribahasa ini akan membungkam mulut seseorang karena merasa tersindir.

Peribahasa ini memiliki makna tahu diri, bahwa seorang anak seharunya membalas kebaikan kedua orang tuanya, bukan mendurhakainya, sifat durkaha tersebut menggambarkan sifat seorang tidak tahu diri sebagai seorang anak.

\section{Peribahasa berbentuk mamang berfungsi sebagai media pendidikan dan pedoman tingkah laku, bermakna teguh pendirian.}

Barek samo dipikua, ringan samo dijinjiang. Terjamahan, 'Berat sama dipikul, ringan sama dijinjing.'

Berat sama dipikul ringan sama dijinjing memiliki bentuk mamang karena memiliki ciriciri berupa petuah kepada suatu kebaikan. Berat sama dipikul memiliki petuah kebaikan berupa tata cara melakukan suatu pekerjaan yang berat, pekerjaan tersebut harus dilakukan dengan cara yang benar agar tidak terasa sulit dalam mengerjakannya, begitu juga dengan ringan sama dijinjing merupakan petuah kebaikan untuk melakukan suatu pekerjaan ringan, karena pekerjaan ringan tidak membutuhkan tenaga yang kuat asalkan pekerjaan itu dilakukan dengan tata cara yang benar.

Peribahasa ini berfungsi sebagai media pendidikan dan pedoman tingkah laku, dengan peribahasa ini seseorang akan diajarakan dan dididik untuk melakukan suatu pekerjaan yang 
berat dan ringan sesuai dengan tata caranya, agar pekerjaan yang berat terasa lebih mudah dan perkejaan yang mudah tidak membuang tenaga.

Peribahasa ini memiliki makna teguh pendirian, maksudnya seorang akan memiliki pendirian dalam menyelesaikan suatu pekerjaan, tidak mudah bosan dan merasa lebih nyaman dengan pekerjaannya.

Peribahasa berbentuk pemeo, Peribahasa ini berfungsi sebagai pengatur aspek-aspek kehidupan bermasyarkat dan bermakna menjaga diri.

Bak cando ayam kailangan induak. Terjemahan, 'Seperti ayam kehilangan induk.'

Seperti ayam kehilangan induk peribahasa ini memiliki ciri-ciri bentuk pemeo yaitu kata-katanya berisi hinaan dan sindiran. Dalam peribahasa ini hinaan dan sindiran tersebut ditujukan kepada seorang anak yang tidak terurus dengan menggunakan nama hewan yaitu ayam. Sindiran dan hinaan tersebut juga ditujukan kepada orang tua yang tidak mau mengurusi anak-anaknya, sehingga anak-anaknya seperti anak yang terlantar, sindiran itu disampaiakan dengankata-kata kehilangan induk. Kata ayam memiliki arti seorang anak, dan kata induk memiliki arti orang tua.

Peribahasa ini berfungsi sebagai pengatur aspek-aspek kehidupan bermasyarkat. Dengan peribahasa ini masyarakat umumnya dan orang tua khusunya agar mengurusi dan bertanggung jawab terhadap anak-anaknya, yaitu dengan memberikan mereka pakaian yang layak, kasih sayang, pendidikan dan tempat tinggal.

Peribahasa ini memiliki makna menjaga diri. Maksudnya, apabila orang tua mencukupi segala kebutuhan hidup anak-anaknya lahir dan batin, maka dengan sedirinya anak-anak akan dapat berbagai pelajaran bagaimana mereka menjaga dan merawat dirinya.

Peribahasa berbentuk tamsil berfungsi sebagai sumber hukum pengawas dan pengukuh normanorma sosial. makna Persatuan/mufakat.

Ndak mungkin silumpuah kabajalan ndak kamungkin sibuto kamancaliak. Terjemahan, 'Tidak mungkin yang lumpuh akan berjalan dan tidak mungkin si buta akan melihat.

Tidak mungkin yang lumpuh akan berjalan dan tidak mungkin si buta akan melihat peribahasa ini memiliki ciri-ciri bentuk tamsil yaitu kata-katanya berisi penjelasan yang diumpamakan terhadap seseorang. Penjelasan tersebut ditujukan kepada seorang atasan, untuk tidak memaksa bawahannya melakukan sesuatu pekerjaan diluar kesanggupan yang dimilikinya.

Apabila dalam bekerja, seseorang manusia tidak akan mungkin bekerja siang dan malam tampa henti, karena itu sudah melagar kodratnya sebagai manuasia, yang memiliki kemampuan terbatas. Kata lumpuh dan buta memiliki arti kemampuan dan kesanggupan yang dimiliki seseorang. Kata berjalan dan melihat memiliki arti batasan dari kemampuan manusia tersebut.

Peribahasa ini berfungsi sebagai sumber hukum pengawas dan pengukuh normanorma sosial. Dengan peribahasa ini seseorang atasan akan lebih mengerti bagaimana memperlakukan bawahannya, dan seorang atasan juga akan lebih faham bagaimana akibat yang akan diterimannya apabila menyengsarakan kehidupan bawahannya.

Peribahasa ini memiliki makna Persatuan/mufakat. Maksudnya, untuk menyadarkan atasan yang semena-mena terhadap bawahannya, persatuan/mufakat bersama antara bawahan dan atasan merupakan bagian terpenting agar tercapai sebuah keadilan dan jalan keluar. 
Peribahasa berbentuk ibarat berfungsi sebagai pengatur aspek kehidupan masyarakat bermakna kesabaran.

Ibaraik batenggang kabanang salai. Terjemahan, 'Ibarat bertenggang ke benang sehelai.

Ibarat bertenggang ke benang sehelai peribahasa ini memiliki ciri-ciri bentuk ibarat karena kata awalnya menggunakan kata ibarat serta kalimatnya berisi perbandingan dengan alam, benda atau pun keadaan disekitarnya. Perbandingan yang terdapat dalam peribahasa ini adalah perbandingan antara benda berupa benang sehelai dengan keadaan yang dialami seseorang.

Keadaan tersebut yaitu seseorang yang meminta bantuan kepada orang yang dalam kesulitan, baik kehidupan materinya maupun kehidupan keluarganya, sehingga permintaan orang tersebut tidak terpenuhi dikarenakan meminta tolong kepada orang yang salah. Kata bertenggang memiliki arti meminta bantuan atau pertolongan, benang sehelai memiliki arti orang yang kesulitan.

Peribahasa ini berfungsi sebagai pengatur aspek kehidupan masyarakat. Dengan peribahasa ini seseorang akan mengerti bagaimana hidup lebih mandiri dan tidak hanya mengandalkan bantuan dari orang lain, aspek tersebut merupakan bagian dari aturan kehidupan yang dijalani.

Peribahasa ini memiliki makna berupa kesabaran, bahwa seseorang harus memiliki sifat sabar untuk meminta bantuan dari orang lain, dan jangan memaksa agar seseorang ingin menolong kita.

Peribahasa berbentuk kata-kata arif, berfungsi sebagai lambang identitas budaya dan sumber informasi budaya, memiliki makna persatuan/mufakat.

Basuluah jo matohari bagalangang jo mato rang nan banyak. Terjemahan, Bersuluh dengan matahari bergelangang dengan mata orang banyak. 'Bersinar dengan matahari bergelangang dengan mata orang banyak.'

Bersinar dengan matahari, bergelanggang dengan mata orang banyak peribahasa ini memiliki ciri-ciri bentuk kata-kata arif karena kata-katanya berisi nasehat kearifan. Nesehat kearifan dalam peribahasa ini berupa gambaran dari hasil mufakat bersama antara tokoh adat dan masyarakat Minangkabau. Hukum tertinggi dalam adat Minangkabau adalah kesepakatan bersama antara masyarakat dengan tokoh adat.

Bersuluh dengan memiliki arti keadilan untuk seluruh manusia. Kata suluh merupakan alat atau cara menjalankan keadilan, kata matahari menunjukan keadilan yang menyinari segalanya, dan kata bergelanggang memiliki arti disaksikan, dan disepakti. Mata orang banyak memiliki arti semua masyarakat.

Peribahasa ini berfungsi sebagai lambang identitas budaya dan sumber informasi budaya. Melalui peribahasa ini seseorang akan mengetahiu informasi tentang adat Minangkabau yang di jalankan berdasarkan persatuan dan mufakat.

Peribahasa ini memiliki makna persatuan/mufakat. Maksudnya, keputusan terbaik dari sebuah persoalan adalah persatuan. Dalam adat Minangkabau tidak mengenal istilah kasta atau tingkatan, semua orang akan dipandang sama, apabila dia mendapat masalah secara adat baik dia orang kaya, miskin, masyarakat biasa atau tokoh adat tetap akan dihukum sesuai dengan hukum adat yang sudah dimusyawarahkan.

Peribahasa berbentuk perumpamaan, berfungsi sebagai sumber hukum dan pengatur normanorma sosial, memiliki makna berupa nilai etika.

Kalah limau dek binalu kalah pusako dek pancarian. Terjemahan, Kalah pohon karena benalu kalah harta pusaka karna harta pencarian. 'Pohon akan binasa karena benalu harta pusaka akan kalah karena harta pencarian.'

Pohon binasa karena benalu kalah pusako dek pancarian peribahasa ini memiliki ciriciri perumpamaan karena kata-katanya berisi dua perbandingan yang berbeda namun dianggap 
sama. Perbandingan yang terdapat dalam peribahasa ini adalah perbandingan antara pohon binasa karena benalu dengan kejadian yang dialami manusia, hal tersebut berbeda namun dianggap sama, yaitu pohon memiliki arti kehidupan orang yang gigih berjuang. Kata benalu mempunyai arti orang yang suka menganggu kehidupan orang lain.

Perbandingan antara kata pusaka dan pencarian yang dibandingan dengan kejadian yang dialami manusia. Bahwa harta pusaka memiliki arti harta pemberian dari orang tua dan harta pencarian memiliki arti harta yang dihasilkan oleh seorang anak, kejadian yang dimaksud oleh peribahasa ini adalah harta pemberian orang tua yang memiliki jumlah lebih sedikit dibandingkan dengan harta pencarian sendiri. Perbandingan ini juga mengambarkankehidupan seseorang yang gigih berjuang dengan orang yang pemalas yang suka bergantung hidup dengan orang lain.

Peribahasa ini berfungsi sebagai sumber hukum dan pengatur norma-norma sosial. Dengan peribahasa ini seseorang akan lebih menyadari bahwa sifat pemalas dan tidak ingin berusaha merupakan sifat yang akan menimbulan pemikiran bahwa hidup bergantung terhadap orang lain merupakan pilihan terbaik, namun hal tersebut merupakan hal yang salah di dalam sumber hukum yang terdapat di dalam adat Minangkabau.

Peribahasa ini memiliki makna berupa nilai etika, bahwa seorang anak yang hanya mengharapkan harta pemberian orang tuanya dan tidak ingin berusaha untuk hidup lebih mandiri merupakan suatu kesalahan terhadap nilai etika pada orang tua.

\section{PENUTUP}

\section{Kesimpulan}

Kesimpulan yang diperoleh dari hasil dan pembahasan tentang peribahasa Minangkabau di Pasaman Barat kajian bentuk, fungsi, dan makna di atas adalah sebagai berikut. (1) bentuk peribahasa Minangkabau dapat diklasifikasikan menjadi (a) kiasan, (b) mamang, (c) pemeo, (d) tamsil, (e) ibarat, (f) kata-kata arif, (g) petatah-petitih, dan (h) perumpamaan. antuhan atau ungkapan dengan bagian tumbuhan.

(2) Fungsi yang terdapat dalam peribahasa Minangkabau, yaitu (a) sebagai media pendidikan dan pedoman tingkah laku, (b) mengatur aspek-aspek kehidupan bermasyarakat, (c) sebagai sumber hukum pengasah pranata sosial, pengawas dan pengukuh normah-norma sosial, (d) lambang identitas budaya dan sumber informasi budaya, dan (f) sebagai media dan sarana retorika untuk mematahkan kata-kata lawan bicara (alat pertahanan diri). (3) Makna yang terkandung dalam peribahasa Minangkabau yang ada di Pasaman Barat, yaitu (a) teguh pendirian, (b) malu, (c) nilai etika, (d) tahu diri, (e) menjaga diri, (f) persatuan mufakat, dan (g) kesabaran.

\section{Saran}

Saran yang ingin disampaikan dalam penelitian ini kiranya perlu dilakukan penelitian sejenis dengan tempat dan karakteristik yang berbeda dan mengharapkan agar penelitian berikutnya meneliti tentang peribahasa secara mendalam dan luas. Peneliti mengharapkan agar penelitian ini menjadi acuan untuk penelitian tentang peribahasa di tempat-tempat lain.

\section{DAFTAR PUSTAKA}

Pulungan, Anni Holida. (2013). Kajian Etnolinguistik Terhadap Peribahasa Dalam Bahasa Indonesia: Sebuah Tinjauan Force (Daya Pragmatik). Journal Etnolinguistik Terhadap Peribahasa, (online) 1 - 9. (hhtps://www.google. co.id), diakses 20 januari 2015.

Danandjaya, James.1982. Folklor Indonesia: Ilmu Gosip, Dongeng, Dan Lain-Lain. Jakarta: Grafiti.

Endah, Nila. 2013. Sarikata Bahasa Indonesia, Pedoman Umum Ejaan Bahasa Indonesia. Jawa Tengah: Media Pustaka 
Ganie, Noor Tadjuddin. 2015. Buku Induk Bahasa Indoenesia (Pantun, Puisi, Syair, Peribahasa, Dan Majas). Yogyakarta: Araska Publisher.

Pusposaputro, Sarwono. 2010. Kamus Peribahasa. Jakarta. PT. Gramedia.

Sudaryanto. 1988. Metode Linguistik, Bagian Kedua, Metode Dan Aneka Teknik Pengumpulan Data.Yogyakarta: Atma Pustaka.

Sugiyono. 2010. Memahami Penelitian Kualitatif. Bandung: Angkasa. 